\title{
Note
}

\section{Detection of brominated and chlorinated organics by a gas chromato- graphic microcoulometric detector}

\section{Effect of pyrolysis tube conditions}

\section{J. A. SWEETMAN*** and E. A. BOETTNER}

Department of Environmental and Industrial Health, University of Michigan, Ann Arbor, MI 48109 (U.S.A.) (Received April 8th, 1981)

The specific detection of halogenated organics is of considerable interest to environmental scientists. Low levels of organochlorine pesticides, polychlorinated biphenyls (PCBs), and polybrominated biphenyls (PBBs) entering the environment are important because of their refractory nature and potential for bioaccumulation. Low levels of some other halogenated compounds, such as haloforms, which are produced during the chlorine disinfection of water ${ }^{1-3}$ must be monitored because thcy may be directly ingested by humans.

Gas chromatography (GC) with an electron-capture detector (ECD) is often used for the analysis of haloforms extracted from waters ${ }^{4.5}$, as well as organochlorine pesticides, $\mathrm{PCB}$, and $\mathrm{PBB}$ residues ${ }^{6}$. The ECD is used because of its sensitivity for halogenated compounds and its wide availability. The ECD has some disadvantages including: a lack of specificity; widely varying sensitivity with degree of chlorination, e.g. the ECD is $10^{4}$ times more sensitive to $\mathrm{CHCl}_{3}$ than to $\mathrm{CH}_{3} \mathrm{Cl}$ (ref. 7); and sensitivity which varies with positional isomerism, e.g. different sensitivity for PCB isomers having the same degree of chlorination ${ }^{8}$. Microcoulometric detection does not have these disadvantages.

The microcoulometric detector responds to the weight of halogen present. Through oxidative pyrolysis the material is converted to titratable halides which are swept into the microcoulometric detector cell where the halides react with the silver ions present in the cell electrolyte. The efficiency of this pyrolysis process varies with compound, pyrolysis temperature, and furnace atmosphere. The coulometer produces a voltage proportional to the current required to replace the consumed silver ions. The detector has a selectivity of $10^{6}$ for chlorine over carbon and of $10^{4}$ for chlorine over sulfur, nitrogen and phosphorus ${ }^{9}$. Microcoulometric detection has been used to measure total organic halogen as a water quality parameter using a system with a sample boat for sample introduction ${ }^{10}$.

In this paper the use of a commercially available microcoulometric detector specifically designed as a GC detector, the Envirotech (Santa Clarâ, CA, U.S.A.)

^ Present address: Department of Chemistry, University of Waterloo, Waterloo, Ontario N2L 3G1, 
Dohrmann DE-20, is discussed. Pyrolysis tube conditions were varied and the effect on the detection of certain halogenated organics including chloroform, bromoform, and halogenated benzenes was examined. At a pyrolysis tube temperature of $925^{\circ} \mathrm{C}$, the analyses of four PBBs were compared.

\section{EXPERIMENTAL}

\section{Solutions for microcoulometric detection}

To avoid carbonaceous build-up in the pyrolysis tube, the solvent used to introduce the halogenated compounds into the GC system must be vented. Pentane was found to be a suitable solvent for the aliphatic halogens and halogenated benzenes studied. Hexane was utilized for the PBBs examined. Table I lists the columns and temperature programs utilized.

\section{TABLE I}

GC COLUMNS AND TEMPERATURE PROGRAMS UTILIZED FOR MICROCOULOMETRIC DETECTION

\begin{tabular}{|c|c|c|}
\hline Compounds & $\begin{array}{l}\text { Retention } \\
\text { time (min) }\end{array}$ & Column and temperature program \\
\hline $\begin{array}{l}\text { Chloroform } \\
\text { 1,2-Dichloroethane } \\
\text { Dibromethane } \\
\text { Bromoform }\end{array}$ & $\begin{array}{r}4.8 \\
6.5 \\
11.5 \\
19.5\end{array}$ & $\begin{array}{l}\text { 4-ft. } 10 \% \text { Carbowax } 20 \mathrm{M} \text { column. } \\
\text { Isothermal at } 75^{\circ} \mathrm{C} \text { for } 8 \mathrm{~min} \text {, } \\
\text { then } 5^{\circ} \mathrm{C} / \mathrm{min} \text { to } 130^{\circ} \mathrm{C} \text {. }\end{array}$ \\
\hline $\begin{array}{l}\text { Chlorobenzene } \\
\text { Bromobenzene } \\
\text { 1,2,4-Trichlorobenzene } \\
\text { 1,2,4-Tribromobenzene }\end{array}$ & $\begin{array}{r}2.5 \\
4.1 \\
11.4 \\
14.6\end{array}$ & $\begin{array}{l}\text { 6-ft. } 3 \% \mathrm{SE}-30 \text { column. } \\
\text { Isothermal at } 68^{\circ} \mathrm{C} \text { for } 6 \mathrm{~min} \text {, } \\
\text { then } 10^{\circ} \mathrm{C} / \mathrm{min} \text { to } 150^{\circ} \mathrm{C} \text {. }\end{array}$ \\
\hline $\begin{array}{l}\text { 2,4-Dibromobiphenyl } \\
\text { 2,4',5-Tribromobiphenyl } \\
2,2^{\prime}, 5,5^{\prime} \text {-Tetrabromobiphenyl } \\
2,2^{\prime}, 4,4^{\prime}, 5,5^{\prime} \text {-Hexabromobiphenyl }\end{array}$ & $\begin{array}{r}2.5 \\
5.5 \\
8.0 \\
15.4\end{array}$ & $\begin{array}{l}6 \text {-ft. } 3 \% \mathrm{SE}-30 \text { column. } \\
\text { Isothermal at } 220^{\circ} \mathrm{C} \text { for } 7 \mathrm{~min} \text {, } \\
\text { then } 15^{\circ} \mathrm{C} / \mathrm{min} \text { to } 290^{\circ} \mathrm{C} \text {. }\end{array}$ \\
\hline
\end{tabular}

Three solutions for recovery studies with microcoulometric detection were prepared, each containing four structurally related compounds. Microliter quantities of $\mathrm{CHCl}_{3}, \mathrm{CHBr}_{3}, \mathrm{ClCH}_{2} \mathrm{CH}_{2} \mathrm{Cl}$, and $\mathrm{CH}_{2} \mathrm{Br}_{2}$ were injected with a Hamilton 10- $\mu$ l syringe into $10 \mathrm{ml}$ of pentane. This stock solution was then diluted 1 to 50 to achieve the desired concentration for microcoulometric detection. The solution concentration was calculated from the density of the individual components. A solution containing three halogenated benzenes was prepared in the same manner; the fourth component, a tribromobenzene, was weighed on a microbalance. Four stock PBB standards (2,4dibromo-, 2,4',5-tribromo-, 2,2',5,5'-tetrabromo-, and 2,2',4,4',5,5'-hexabromobiphenyl obtained from RFR, Hope, RI, U.S.A.) were prepared by weighing mg quantities and transferring to 100 -ml flasks with hexane. The final PBB solution was prepared by mixing $2 \mathrm{ml}$ each of the four PBB stock solutions. 


\section{Instrumental}

An Envirotech DE-20 halogen specific microcoulometric GC detector was adapted to a Microtek MT-220 GC. The effluent from the GC column flows through a transfer line (wrapped in heating tape and kept at the maximum column temperature) to a pyrolysis tube in a furnace which is at $820^{\circ} \mathrm{C}$ or higher. As the GC effluent enters the pyrolysis tube it is joined by a $120 \mathrm{ml} / \mathrm{min}$ flow of oxygen. The halogenated species are converted to titratable halides and swept into the miniaturized microcoulometric cell.

A Texas Instruments strip chart recorder was used to record the voltage produced by the coulometer. A compensating polar planimeter ( $K \& E$ ) was used to measure the areas of the GC peaks for conversion to ng halide as follows:

$$
\text { halide }(\mathrm{ng})=\frac{\mathrm{GC} \text { peak area (coulombs) } \times 10^{9} \times \text { atomic wt. of halide }}{96500 \text { (faraday) }}
$$

RESULTS AND DISCUSSION

Table II gives the results of triplicate injections of the solution containing $\mathrm{CHCl}_{3}, \mathrm{ClCH}_{2} \mathrm{CH}_{2} \mathrm{Cl}, \mathrm{CH}_{2} \mathrm{Br}$, and $\mathrm{CHBr}_{3}$. Three pyrolysis tube temperatures, the lowest being the manufacturers recommended value of $820^{\circ} \mathrm{C}$, were used. The \% recoveries were determined as $100 \times$ the ratio of the amount of halide represented by the GC peak area to the amount of halide equivalent to complete conversion of the organic halogen compound to titratable halides. For $\mathrm{CHCl}_{3}$ and $\mathrm{ClCH}_{2} \mathrm{CH}_{2} \mathrm{Cl}$ with oxygen pyrolysis gas the recovery could be increased by increasing the pyrolysis tube temperature. More complete pyrolysis to titratable halide probably results at the high

\section{TABLE II}

MICROCOULOMETRIC DETECTION OF $\mathrm{CHCl}_{3}, \mathrm{ClCH}_{2} \mathrm{CH}_{2} \mathrm{Cl}, \mathrm{CHBr}_{3}, \mathrm{CH}_{2} \mathrm{Br}_{2}$ WITH OXYGEN OR CARBON DIOXIDE REACTANT

\begin{tabular}{|c|c|c|c|c|c|}
\hline \multirow{2}{*}{$\begin{array}{l}\text { Reactant } \\
\text { gas }\end{array}$} & \multirow{2}{*}{$\begin{array}{l}\text { Pyrolj:sis tube } \\
\text { temperature }\left({ }^{\circ} \mathrm{C}\right)^{\star}\end{array}$} & \multicolumn{4}{|c|}{ Recovery $(\%) \pm$ S.D. $(n=3)$} \\
\hline & & $\begin{array}{l}\mathrm{CHCl}_{3} \\
\left(66 \mathrm{ng} \mathrm{Cl}^{-}\right)^{\star \star}\end{array}$ & $\begin{array}{l}\mathrm{ClCH}_{2} \mathrm{CH}_{2} \mathrm{Cl} \\
\left(53 \mathrm{ng} \mathrm{Cl}^{-}\right)^{\star \star}\end{array}$ & $\begin{array}{l}\mathrm{CHBr}_{3} \\
\left(137 \mathrm{ng} \mathrm{Br}^{-}\right)^{\star \star}\end{array}$ & $\begin{array}{l}\mathrm{CH}_{2} \mathrm{Br}_{2} \\
\left(138 \mathrm{ng} \mathrm{Br}^{-}\right)^{\star \star}\end{array}$ \\
\hline \multirow[t]{3}{*}{$\mathrm{O}_{2}$} & 820 & $42 \pm 1.5$ & $41 \pm 2.1$ & $82 \pm 2.6$ & $77 \pm 1.7$ \\
\hline & 920 & $47 \pm 1.2$ & $73 \pm 1.5$ & $55 \pm 3.6$ & $53 \pm 4.2$ \\
\hline & 1020 & $47 \pm 1.0$ & $64 \pm 2.5$ & $39 \pm 4.7$ & $43 \pm 2.1$ \\
\hline \multirow[t]{3}{*}{$\mathrm{CO}_{2}$} & 820 & $40 \pm 2.0$ & $45 \pm 5.0$ & $68 \pm 3.8$ & $79 \pm 4.5$ \\
\hline & 920 & $48 \pm 2.3$ & $76 \pm 1.5$ & $82 \pm 2.3$ & $91 \pm 2.3$ \\
\hline & 1020 & $66 \pm 3.0$ & $92 \pm 3.5$ & $81 \pm 2.9$ & $87 \pm 0.6$ \\
\hline
\end{tabular}

$\star$ Deviation from specified temperatures $\pm 10^{\circ} \mathrm{C}$.

$\star \star$ Amount of chloride or bromide equivalent to complete conversion of organic halogen compound to titratable halides. 
temperatures. For $\mathrm{CHBr}_{3}$ and $\mathrm{CH}_{2} \mathrm{Br}_{2}$ the opposite effect occurs. The recovery decreases with increased pyrolysis tube temperature (see Fig. 1). The brominated compounds may be converted to a nontitratable species such as bromate $\left(\mathrm{BrO}_{3}\right)$. Using carbon dioxide as the pyrolysis gas, the pyrolysis tube temperature could be increased without decreasing the recovery of brominated compounds. Comparable recoveries for the chlorinated compounds resulted with carbon dioxide as pyrolysis gas.
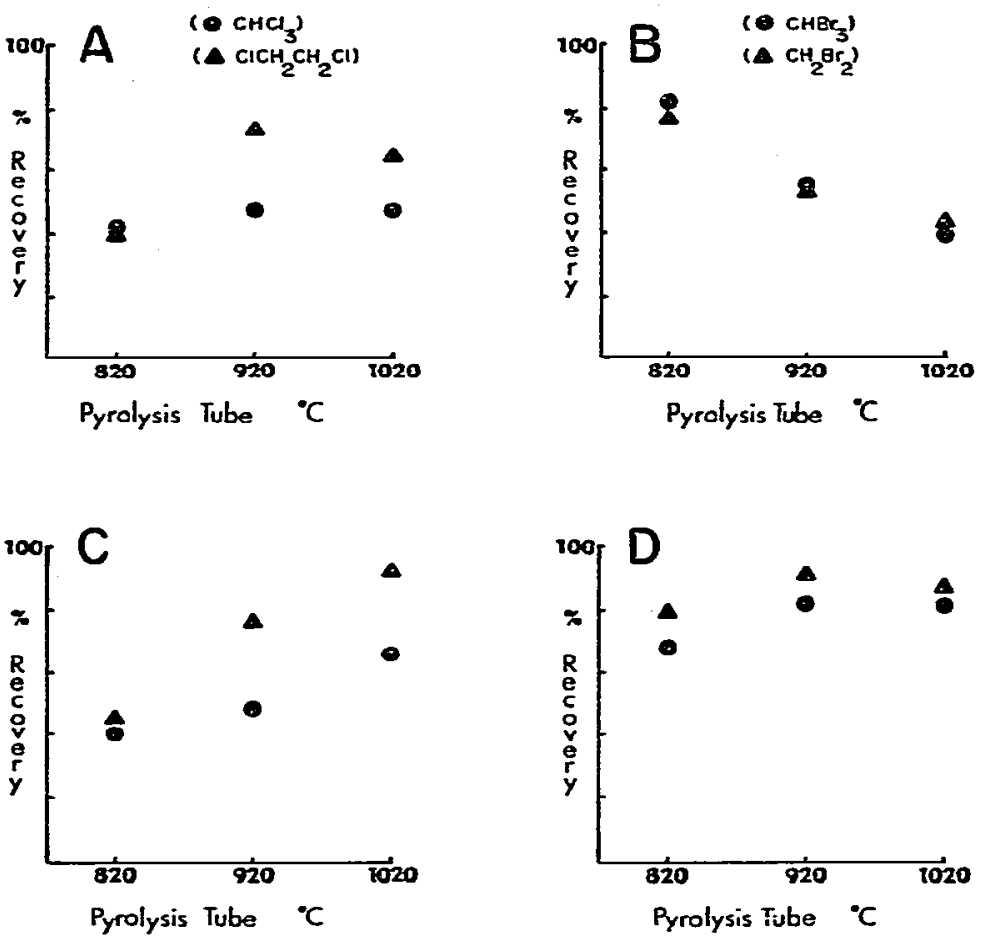

Fig. 1. Effect of pyrolysis gas and pyrolysis tube temperature on recovery. Chlorinated compounds $\mathrm{A}$ and $\mathrm{C}$; $\mathrm{CHCl}_{3}, \mathrm{~A} \mathrm{ClCH}_{2} \mathrm{CH}_{2} \mathrm{Cl}$. Brominated compounds $\mathrm{B}$ and $\mathrm{D} ; \odot \mathrm{CHBr}_{3}, \mathrm{~A} \mathrm{CH}_{2} \mathrm{Br}_{2}$. A and $\mathrm{B}$ : Oxygen reactant gas; $C$ and $D$ : carbon dioxide reactant gas.

With oxygen as the pyrolysis gas, halogenated benzenes showed very poor recovery at $820^{\circ} \mathrm{C}$ (Table III). For both chlorinated and brominated benzenes, the recoveries increased with higher pyrolysis tube temperatures. The aromatic carbonhalogen bond is stronger than the aliphatic carbon-halogen bond. For example, the $\mathrm{C}-\mathrm{Br}$ bond energy of bromobenzene is $71 \mathrm{kcal} / \mathrm{mole}$; and the $\mathrm{C}-\mathrm{Br}$ bond energy of ethyl bromide is $65 \mathrm{kcal} / \mathrm{mole}^{11}$. As a result, it would be expected that pyrolysis of the aromatic compounds require higher temperatures. Recovery of the bromobenzenes, as would be expected from the weaker $\mathrm{C}$-halogen bond was better than recovery of the chlorobenzenes $(\mathrm{C}-\mathrm{Cl}, 86 \mathrm{kcal} / \mathrm{mole})$. Recoveries similar to the brominated benzenes were found (Table IV) for four PBB isomers (2-6 bromine atoms) using oxygen pyrolysis gas and a $925^{\circ} \mathrm{C}$ pyrolysis tube temperature.

Differences in thermal stability have been utilized to selectively detect chlorinated pesticides in the presence of $\mathrm{PCBs}$ with a Coulson electrolytic conductivity detector in the reductive mode ${ }^{12,13}$. It appears that the same sort of selective detection 
TABLE III

MICROCOULOMETRIC DETECTION OF HALOGENATED BENZENES WITH OXYGEN REACTANT

\begin{tabular}{|c|c|c|c|c|}
\hline \multirow{2}{*}{$\begin{array}{l}\text { Pyrolysis } \\
\text { tube } \\
\text { temperature }\left({ }^{\circ} \mathrm{C}\right)^{\star}\end{array}$} & \multicolumn{4}{|c|}{ Recovery $(\%) \pm S . D .(n=3)$} \\
\hline & $\begin{array}{l}\text { Chloro- } \\
\text { benzene } \\
\left(87 \mathrm{ng} \mathrm{Cl}^{-}\right)^{\star \star}\end{array}$ & $\begin{array}{l}\text { Bromo- } \\
\text { benzene } \\
\left(136 n g \mathrm{Br}^{-}\right)^{\star \star}\end{array}$ & $\begin{array}{l}\text { 1,2,4-Tri- } \\
\text { chlorobenzene } \\
\left(86 \mathrm{ng}\left(\mathrm{Cl}^{-}\right)\right.\end{array}$ & $\begin{array}{l}\text { 1,2,4-Tri- } \\
\text { bromobenzene } \\
\left(175 \mathrm{ng} \mathrm{Br}^{-}\right)^{\star \star}\end{array}$ \\
\hline 820 & $<5$ & $<5$ & $<5$ & $<5$ \\
\hline 870 & $14 \pm 0.6$ & $16 \pm 1.2$ & $3 \pm 1.2$ & $10 \pm 2.5$ \\
\hline 920 & $28 \pm 3.6$ & $47 \pm 5.7$ & $18 \pm 3.2$ & $40 \div 2.9$ \\
\hline 1020 & $26 \pm 2.1$ & $50 \pm 1.0$ & $26 \pm 1.7$ & $47 \pm 4.4$ \\
\hline
\end{tabular}

$\star$ Deviation from specified temperatures $\pm 10^{\circ} \mathrm{C}$.

« Amount of chloride or bromide equivalent to complete conversion of organic halogen compound to titratable halides.

could be accomplished with the microcoulometric detector in the oxidative mode. The results with $\mathrm{CHBr}_{3}$ and $\mathrm{CH}_{2} \mathrm{Br}_{2}$ point out, however, that if high pyrolysis tube temperatures are used to screen for all halogenated organics, there will be a tendency to discriminate against the aliphatic brominated organics. On the basis of this limited study, it is evident that to achieve maximum sensitivity by microcoulometric detection, the pyrolysis process must be optimized and for quantitation, standards must be used to determine the recovery for each compound.

\section{TABLE IV}

MICROCOULOMETRIC DETECTION OF PBBS WITH OXYGEN REACTANT

Pyrolysis tube temperature $925 \pm 7^{\circ} \mathrm{C}$.

\begin{tabular}{lrl}
\hline Isomer & Amount* & $\begin{array}{l}\text { Recovery of } P B B \\
(\%) \pm S . D .(n=3)\end{array}$ \\
\hline 2,4-Dibromobiphenyl & $73.4 \mathrm{ng} \mathrm{Br}^{-}$ & $43 \pm 7.8$ \\
2,4',5-Tribromobiphenyl & $49.5 \mathrm{ng} \mathrm{Br}^{-}$ & $34 \pm 4.0$ \\
$2,2^{\prime}, 5,5^{\prime}-$ Tetrabromobiphenyl & $69.8 \mathrm{ng} \mathrm{Br}^{-}$ & $35 \pm 6.8$ \\
$2,2^{\prime}, 4,4^{\prime}, 5,5^{\prime}$-Hexabromobiphenyl & $123.6 \mathrm{ng} \mathrm{Br}^{-}$ & $44 \pm 7.8$ \\
\hline
\end{tabular}

* Amount of bromide equivalent to complete conversion of the PBB to titratable bromide.

\section{ACKNOWLEDGEMENT}

This work was supported in part by a research contract with the Michigan Department of Health.

\section{REFERENCES}

1 J. C. Morris, Formation of Halogenated Organics by Chlorination of Water Supplies, EPA-600/1-75-002. Office of Research and Development, U.S. Environmental Protection Agency, Washington, DC, 1975. 
2 R. L. Jolley, (Editor), The Environmental Impact of Water Chlorination, Conference Proceedings, CONF.751096, Oak Ridge National Laboratory, Oak Ridge, TN, 1976.

3 R. L. Jolley, H. Gorchev and D. H. Hamilton, Jr., (Editors), Water Chlorination Environmental Impact and Health Effects, Vol. 2, Ann Arbor Sci. Publ., Ann Arbor, MI, 1978.

4 W. H. Glaze and R. Rawley, J. Amer. Water Works Ass., 71 (1979) 509.

5 A. R. Trussell, M. D. Umphres, L. Y. C. Leong and R. R. Trussell, J. Amer. Water Works Ass., 71 (1979) 385.

6 I. Pomerantz, J. Burke, D. Firestone, J. McKinney, J. Roach and W. Trotter, Environ. Health Perspect., 24 (1978) 133.

7 E. P. Grimsrud and D. A. Miller, Anal. Chem., 50 (1978) 1141.

8 B. Bøe and E. Egaas, J. Chromatogr., 180 (1979) 127.

9 Envirotech Dohrmam DE-20 Microcoulometric Halogen Specific GC Detector, SM-762-027750, Envirotech Corporation, Santa Clara, CA, 1977.

10 W. H. Glaze, G. R. Peyton and R. Rawley, Environ. Sci. Technol., 11 (1977) 685.

11 J. D. Roberts and M. C. Caserio, Basic Principles of Organic Chemistry, W. A. Benjamin, New York, 1965.

12 J. W. Dolan and R. C. Hall, Anal. Chem., 45 (1973) 2198.

13 G. C. C. Su and H. A. Price, J. Agr. Food Chem., 21 (1973) 1099. 